\title{
Postharvest Quality and Ripening of Dwarf Brazilian Bananas (Musa sp.) after X-ray Irradiation Quarantine Treatment
}

\author{
Marisa M. Wall \\ U.S. Department of Agriculture, Agricultural Research Service, U.S. Pacific \\ Basin Agricultural Research Center, P.O. Box 4459, Hilo, HI 96720-0459
}

Additional index words. tropical fruit, disinfestation

\begin{abstract}
Fruit quality and ripening of Dwarf Brazilian bananas (Musa sp., group AAB) were determined after $x$-ray irradiation for disinfestation of quarantine pests. The proximal and distal hands from winter- and summer-harvested bunches were treated with irradiation doses of $0,200,400,600$, or $800 \mathrm{~Gy}$, stored for 7 days at $14{ }^{\circ} \mathrm{C}$, and ripened at $20{ }^{\circ} \mathrm{C}$. Irradiation did not extend banana shelf life or affect soluble solids content, but titratable acidity decreased with increasing dose. Starch and total sugar concentrations were similar for control and irradiated fruit at all doses. However, sucrose contents decreased linearly as dose increased, whereas glucose and fructose concentrations increased, indicating an acceleration of sucrose hydrolysis in treated bananas. Irradiation retarded peel softening but not pulp softening for winter-harvested fruit and had a minimal effect on peel and pulp firmness of summer-harvested fruit. For irradiated fruit, the respiratory climacteric rates decreased relative to control fruit, but $\mathrm{CO}_{2}$ and ethylene production increased 1 day after irradiation stress. Proximal fruit (more mature) had higher respiration rates and produced more ethylene than distal fruit (less mature) after irradiation, but differences in physiological maturity between hands did not affect soluble solids, titratable acidity, starch, or total sugar content of ripe fruit. Bananas from distal hands treated with $800 \mathrm{~Gy}$ irradiation developed peel injury when harvested in either the winter or summer months. Summer-harvested fruit also were damaged at the 600-Gy dose for distal fruit only. Treatment of fruit from the proximal half of bunches at doses $\leq \mathbf{6 0 0}$ Gy would ensure visual quality while providing quarantine security for Dwarf Brazilian bananas.
\end{abstract}

The Dwarf Brazilian banana (Musa sp., group $\mathrm{AAB}$ ) is grown and marketed widely in the Hawaiian islands, where it is known as the "apple" banana (Simmonds, 1954). These specialty bananas contain three times more vitamin $\mathrm{C}$ and 1.5 times more provitamin $\mathrm{A}$ than Cavendish-type bananas (Wall, 2006). Dwarf Brazilian bananas are limited in mainland U.S. and international markets because of quarantine restrictions. The fruit can be exported at the mature green stage under a nonhost quarantine status for Mediterranean [Ceratitis capitata (Wiedemann)], melon [Bactrocera cucurbitae (Coquillet)],

Received for publication 15 Aug. 2006. Accepted for publication 13 Sept. 2006.

Mention of a trademark, warranty, proprietary product, or vendor does not constitute a guarantee by the U.S. Department of Agriculture and does not imply its approval to the exclusion of other products or vendors that may be suitable. I thank Mike Tarring for supplying fruit for the project and Eric Weinert for contributing irradiation services. Sandra Silva, Suzanne Sanxter, Ryan Bosma, and Thomas Winslow provided excellent technical assistance. The cost of publishing this paper was defrayed in part by the payment of page charges. Under postal regulations, this paper therefore must be marked advertisement solely to indicate this fact.

Corresponding author; e-mail mwall@pbarc.ars. usda.gov. inspections for banana moth are considerably easier than for green scale. However, banana fruit injury must be absent or minimal before the 400-Gy treatment can be used commercially. Local growers are interested in exporting irradiated bananas from Hawaii, but quality analyses are needed before markets can be developed and large shipments can be risked.

Most banana irradiation research has been done with Cavendish fruit (Musa spp., group AAA) with uncertain dosimetry. Phytotoxic symptoms generally occurred at target doses $>500$ Gy for preclimacteric fruit (Maxie et al., 1968; Thomas et al., 1971), but some authors report damage at doses as low as 400 Gy (Strydom and Whitehead, 1990). Irradiation injury appears as skin browning and has been attributed to an increase in polyphenol oxidase activity in the peel (Thomas and Nair, 1971). The maximum tolerable dose varied according to cultivar, physiological stage, storage conditions, degree of mechanical damage, and the time interval between harvest and irradiation treatment (Aina et al., 1999; Eric et al., 1970; Thomas et al., 1971). Bananas irradiated with doses up to $600 \mathrm{~Gy}$ tasted similar to control fruit (Strydom and Whitehead, 1990; Thomas et al., 1971). Higher doses (600 to 1000 Gy) may inhibit ethylene production and ripening (Strydom and Whitehead, 1990). During commercial treatment in Hawaii, the dose uniformity ratio for irradiated bananas is $\approx 1.5$; therefore, some fruit may be exposed to $>600$ Gy when trying to achieve a minimum absorbed dose of $400 \mathrm{~Gy}$. No information is available on the ripening behavior and quality of preclimacteric Dwarf Brazilian bananas after low doses $(<1000 \mathrm{~Gy})$ of irradiation. Also, the variability in maturity among hands within a bunch may impact banana radiotolerance and was not considered in previous studies.

\section{Material and Methods}

Fruit harvest. Bananas (Musa sp., Dwarf Brazilian cv 'Santa Catarina Prata', "apple," $\mathrm{AAB}$ group) were harvested on $18 \mathrm{Jan}$. and 21 Feb. 2005 (winter harvest) and 11 May and 2 Aug. 2005 (summer harvest) from a commercial orchard near Keaau, Hawaii. Only mature green (stage 1) fruit were selected. Winter fruit were harvested 19 to 20 weeks after flower emergence. Summer fruit were harvested 17 to 18 weeks after flower emergence. Two bunches were selected at each harvest date for a total of four winter bunches and four summer bunches. A bunch represented a block for statistical analyses. Variation in physiological maturity as a result of hand position on a bunch was partitioned by removing two proximal hands and two distal hands from each bunch for irradiation treatment. The hands were labeled, transported immediately to the laboratory, and cut into clusters with four fruit per cluster.

Irradiation treatment. The clusters from the proximal and distal hands from each 
bunch were randomly assigned to five irradiation treatments $(0,200,400,600$, and 800 Gy). Bananas $(1.5 \mathrm{~kg})$ were placed into fiberboard boxes lined with low-density polyethylene plastic for treatment at a commercial irradiation facility on the island of Hawail (Hawaii Pride LLC, Keaau, Hawaii). Clusters from proximal and distal hands were randomized within a box. The facility uses an electron linear accelerator $(5 \mathrm{MeV}$, model TB-5/15; L-3 Communications Titan Corp., San Diego) and converts the e-beam into $\mathrm{x}$-rays for treatment of produce. Six dosimeters (Opti-chromic detectors, FWT-70-83M; Far West Technology, Goleta, Calif.) were placed inside each box. The dosimeters were read at $600 \mathrm{~nm}$ with a FWT-200 reader (Far West Technology) to determine the dose variation within each box. Bananas were treated with target absorbed doses of 0,200 , 400,600 , or 800 Gy irradiation. Each irradiation dose was replicated four times. For the winter-harvested bananas, the average minimum and maximum absorbed doses inside the boxes were 210-230, 399-439, 604-665, and 814-872 Gy, with corresponding dose uniformity ratios of $1.09,1.10,1.10$, and 1.07 for the $200,400,600$, and 800-Gy target dose treatments, respectively. For the summerharvested bananas, the average minimum and maximum absorbed doses inside the boxes were 188-214, 386-435, 575-635, and 780-851 Gy with corresponding dose uniformity ratios of $1.14,1.13,1.10$, and 1.09 for the 200, 400, 600, and 800-Gy target dose treatments, respectively. After treatment, bananas were stored at $14{ }^{\circ} \mathrm{C}$ and $96 \%$ to $98 \%$ relative humidity $(\mathrm{RH})$ for $7 \mathrm{~d}$ and then ripened at $20{ }^{\circ} \mathrm{C}$ and $95 \% \mathrm{RH}$. Control treatments $(0 \mathrm{~Gy})$ were not subjected to irradiation but were otherwise handled the same as the treated fruit.

Quality and gas analyses. Respiration rates, ethylene production, surface color, peel injury, and fruit weights were measured before and after irradiation treatment and every $2 \mathrm{~d}$ thereafter during the storage and ripening periods until the fruit reached stage
7 of the ripeness scale (Del Monte Fresh Produce, 1992). At that time, final nondestructive measurements were made, and destructive measurements for firmness, soluble solids, titratable acidity, starch content, and sugar concentrations were conducted.

For gas analyses, one finger was removed from each cluster and placed into 2-L glass jars with lids fitted with septa. After $2 \mathrm{~h}$, gas samples were removed for respiration and ethylene measurements using a gas chromatograph (GC-14B; Shimadzu, Kyoto, Japan) with helium as the carrier gas at $50 \mathrm{kPa}$. The GC was equipped with a Poropak QS stainless steel column (100-120 mesh; Supelco, Bellefonte, $\mathrm{Pa}$.), a thermal conductivity detector for $\mathrm{CO}_{2}$ detection, and a flame ionization detector (FID) for ethylene detection. Temperatures were set at $60{ }^{\circ} \mathrm{C}$ for the column and $100{ }^{\circ} \mathrm{C}$ for both detectors. The run time was $5 \mathrm{~min}$.

Degree of ripeness was assessed on peel color using an industry scale of 1 (dark green), 2 (green, trace of yellow), 3 (half green-half yellow), 4 (three-fourths yellow with green), 5 (yellow with green tip), 6 (full yellow), and 7 (yellow with black spots) (Del Monte Fresh Produce, 1992). In addition, surface color measurements were taken at three positions per fruit for all fingers in a cluster with a chromameter (model CR300; Minolta Corp., Ramsey, N.J.) and recorded as lightness $\left(\mathrm{L}^{*}\right)$, chroma $\left(\mathrm{C}^{*}\right)$, and hue angle $\left(\mathrm{h}^{\circ}\right)$ under standard illuminant $C$. Peel injury (scald) was assessed visually and rated as the percentage of the surface area showing grayish discoloration, in which $0=$ $0 \%, 1=1 \%$ to $20 \%, 2=21 \%$ to $40 \%, 3=41 \%$ to $60 \%, 4=61 \%$ to $80 \%$, and $5=81 \%$ to $100 \%$.

Firmness was measured using a force gauge (Ametek, Largo, Fla.) having an 8-mm diameter probe and mounted on a motorized test stand. The peak force (in kilograms) was measured at a penetration depth of $7 \mathrm{~mm}$, and the data were converted to Newtons $(\mathrm{N})$. For soluble solids measurement, a composite sample was created from three fruit and a 10-g sample of pulp was homogenized with $10 \mathrm{~g}$ water for $1 \mathrm{~min}$. The soluble solids of the liquid was measured with a refractometer (Atago, Kirkland, Wash.). Titratable acidity was determined by titration with $0.01 \mathrm{~N} \mathrm{NaOH}$ and calculated as malic acid equivalents.

Starch and sugar analyses. For starch and sugar determinations, pulp (10 g) from three fruit was combined in a test tube and homogenized in $80 \%$ ethanol for $1 \mathrm{~min}$ at high speed. The slurry was immediately boiled for $15 \mathrm{~min}$, cooled, and filtered. The filter cake was rinsed with additional ethanol and dried at $70^{\circ} \mathrm{C}$ to obtain the alcohol insoluble solids (AIS) for starch analysis. The sugar extract was brought to a final volume of $100 \mathrm{~mL}$ with $80 \%$ ethanol. A 5-mL aliquot was reduced under nitrogen gas, the residue was redissolved in $5 \mathrm{~mL}$ double-distilled, deionized water, and filtered through a $0.22-\mu \mathrm{m}$ membrane filter into vials for high-pressure liquid chromatography (HPLC).

HPLC was used to separate and quantify glucose, fructose, and sucrose in the banana samples. Sugars were analyzed by injecting $20 \mu \mathrm{L}$ of sample into an Agilent 1100 series liquid chromatograph (Agilent Technologies, Wilmington, Del.) with HPLC-grade water as the mobile phase and an Aminex HPX-87C carbohydrate analysis column as the stationary phase $(4 \mathrm{~mm}$ ID $\times 250 \mathrm{~mm}, 9 \mu \mathrm{m}$; BioRad, Hercules, Calif.) followed by a refractive index detector. The flow rate was 0.6 $\mathrm{mL} / \mathrm{min}$; the temperatures were $4{ }^{\circ} \mathrm{C}$ for the autosampler, $80^{\circ} \mathrm{C}$ for the column compartment, and $50{ }^{\circ} \mathrm{C}$ for the detector. Sucrose, glucose, and fructose peaks of the samples were identified according to HPLC retention times in comparison with authentic standards. For recovery tests, samples were spiked with standard solutions before extraction. The detection limit was $1 \mu \mathrm{g}$, and the recovery was $93 \%$.

Starch analysis of the AIS was by enzymatic hydrolysis of starch to reducing sugars using the amyloglucosidase method of Hagenimana et al., (1994) as described by

Table 1. Days to ripeness, percent weight loss, and composition of Dwarf Brazilian ('Santa Catarina Prata') bananas after irradiation treatments, storage at $14{ }^{\circ} \mathrm{C}$ for $7 \mathrm{~d}$, and ripening at $20^{\circ} \mathrm{C}$.

\begin{tabular}{|c|c|c|c|c|c|c|c|c|c|}
\hline Dose (Gy) & $\begin{array}{l}\text { Days to } \\
\text { ripe }\end{array}$ & $\begin{array}{c}\text { Wt loss } \\
(\%)\end{array}$ & $\begin{array}{c}\text { Soluble } \\
\text { solids (\%) }\end{array}$ & $\begin{array}{c}\text { Titratable } \\
\text { acidity (\%) }\end{array}$ & $\begin{array}{c}\text { Starch } \\
\left(\mathrm{mg} \cdot \mathrm{g}^{-1} \mathrm{FW}\right)\end{array}$ & $\begin{array}{c}\text { Sucrose } \\
\left(\mathrm{mg} \cdot \mathrm{g}^{-1} \mathrm{FW}\right)\end{array}$ & $\begin{array}{c}\text { Glucose } \\
\left(\mathrm{mg} \cdot \mathrm{g}^{-1} \mathrm{FW}\right)\end{array}$ & $\begin{array}{c}\text { Fructose } \\
\left(\mathrm{mg} \cdot \mathrm{g}^{-1} \mathrm{FW}\right)\end{array}$ & $\begin{array}{c}\text { Total } \\
\text { sugars } \\
\left(\mathrm{mg} \cdot \mathrm{g}^{-1} \mathrm{FW}\right)\end{array}$ \\
\hline 0 & $17.3^{\mathrm{z}}$ & 4.9 & 22.2 & 0.71 & 41.2 & 85.7 & 36.3 & 29.6 & 151.6 \\
\hline 200 & 18.9 & 5.5 & 22.6 & 0.72 & 40.2 & 82.5 & 45.6 & 38.1 & 166.2 \\
\hline 400 & 17.9 & 5.1 & 22.4 & 0.70 & 41.9 & 72.1 & 46.3 & 39.5 & 157.9 \\
\hline 600 & 17.1 & 5.2 & 21.9 & 0.68 & 48.1 & 66.0 & 48.0 & 41.3 & 155.3 \\
\hline \multirow[t]{2}{*}{800} & 18.1 & 5.6 & 22.1 & 0.65 & 46.6 & 60.3 & 50.8 & 45.7 & 156.8 \\
\hline & NS & NS & NS & $\mathrm{L} * * *$ & NS & $\mathrm{L}^{* * *}$ & $\mathrm{~L}^{* * *}$ & $\mathrm{~L}^{* * *}$ & NS \\
\hline \multicolumn{10}{|c|}{ Hand position $^{y}$} \\
\hline Proximal & 16.9 & 4.9 & 22.2 & 0.68 & 45.6 & 65.6 & 49.5 & 43.2 & 158.3 \\
\hline \multirow[t]{2}{*}{ Distal } & 18.8 & 5.6 & 22.3 & 0.70 & 41.6 & 81.1 & 41.3 & 34.4 & 156.8 \\
\hline & $* * *$ & $* * *$ & NS & NS & NS & $* * *$ & $* * *$ & $* * *$ & NS \\
\hline
\end{tabular}

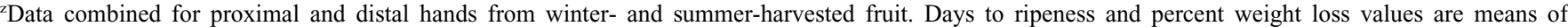
16 replications with four bananas per replication. Soluble solids, titratable acidity, starch, and sugar values are means of 16 replications with a composite sample of three bananas per replication.

yProximal hands were harvested from the top of the bunch, closest to the plant and were more mature than distal hands harvested from the bottom of the bunch. Data combined over irradiation doses for winter- and summer-harvested fruit. Values are means of 40 replications with three to four bananas per replication. NS, *** Nonsignificant at $P>0.05$ or significant at $P \leq 0.001$, respectively. Significant dose-response trends were linear (L). 
Wall (2004). After enzymatic hydrolysis, the total reducing sugars were measured using the method of Blakeney and Mutton (1980).

Statistical analyses. Data for destructive measurements were subjected to analysis of variance using the general linear models (GLM) procedure (SAS Institute, 1999) for a randomized complete block design with four blocks for each experiment (winter harvest and summer harvest). A block consisted of one bunch of fruit. Data for nondestructive measurements were analyzed for repeated measures over time using the GLM procedure. Dose-response was tested by orthogonal polynomial analysis in SAS. Data for each experiment were analyzed separately. After checking for homogeneity of variance, a combined analysis was conducted for those variables in which differences between experiments (harvest season) were not significant and interactions between experiment and main factors were not significant.

\section{Results and Discussion}

Harvest season and interactions were not significant $(P>0.05)$ for days to ripeness, percent weight loss, soluble solids content, percent titratable acidity, and concentrations of starch and sugars. Therefore, data for winter- and summer-harvested fruit were combined for these variables (Table 1). Also, the response to irradiation dose was not impacted by hand position for these variables, but main effects were significant ( $P \leq$ 0.05 for dose and hand position). Dwarf Brazilian bananas ripened 17 to $19 \mathrm{~d}$ after harvest, and irradiation did not extend shelf life as reported in other studies for Cavendish bananas (Maxie et al., 1968). Soluble solids content was unaffected by irradiation dose; however, titratable acidity decreased linearly with increasing irradiation dose, reflecting a possible decrease in organic acids or ascorbic acid in irradiated fruit. Ascorbic acid concentrations can be diminished in irradiated bananas as dose levels increase (Ferguson et al., 1966).

The distal fruit on the bunches ripened $\approx 2 \mathrm{~d}$ later and had greater weight loss than the proximal fruit (Table 1). Proximal fruit had higher respiration and ethylene production rates than distal fruit (Fig. 1). However, differences in physiological maturity between hands did not affect soluble solids, titratable acidity, starch, or total sugar content of ripe fruit.

The respiratory peak of $\mathrm{CO}_{2}$ production reached $155 \mathrm{mg} \cdot \mathrm{kg}^{-1} \cdot \mathrm{h}^{-1}$ for nonirradiated bananas $14 \mathrm{~d}$ after harvest (Fig. 2A). For irradiated bananas, respiratory patterns were altered and $\mathrm{CO}_{2}$ peak rates decreased to 97 to $114 \mathrm{mg} \cdot \mathrm{kg}^{-1} \cdot \mathrm{h}^{-1}$. However, a respiratory increase in response to irradiation stress was evident on day 3 for treated bananas. Respiration rates of fruit irradiated with 400 to 800 Gy remained higher than for control fruit through day 9. Similar studies have shown that irradiation decreased banana climacteric peaks but increased preclimacteric respira-
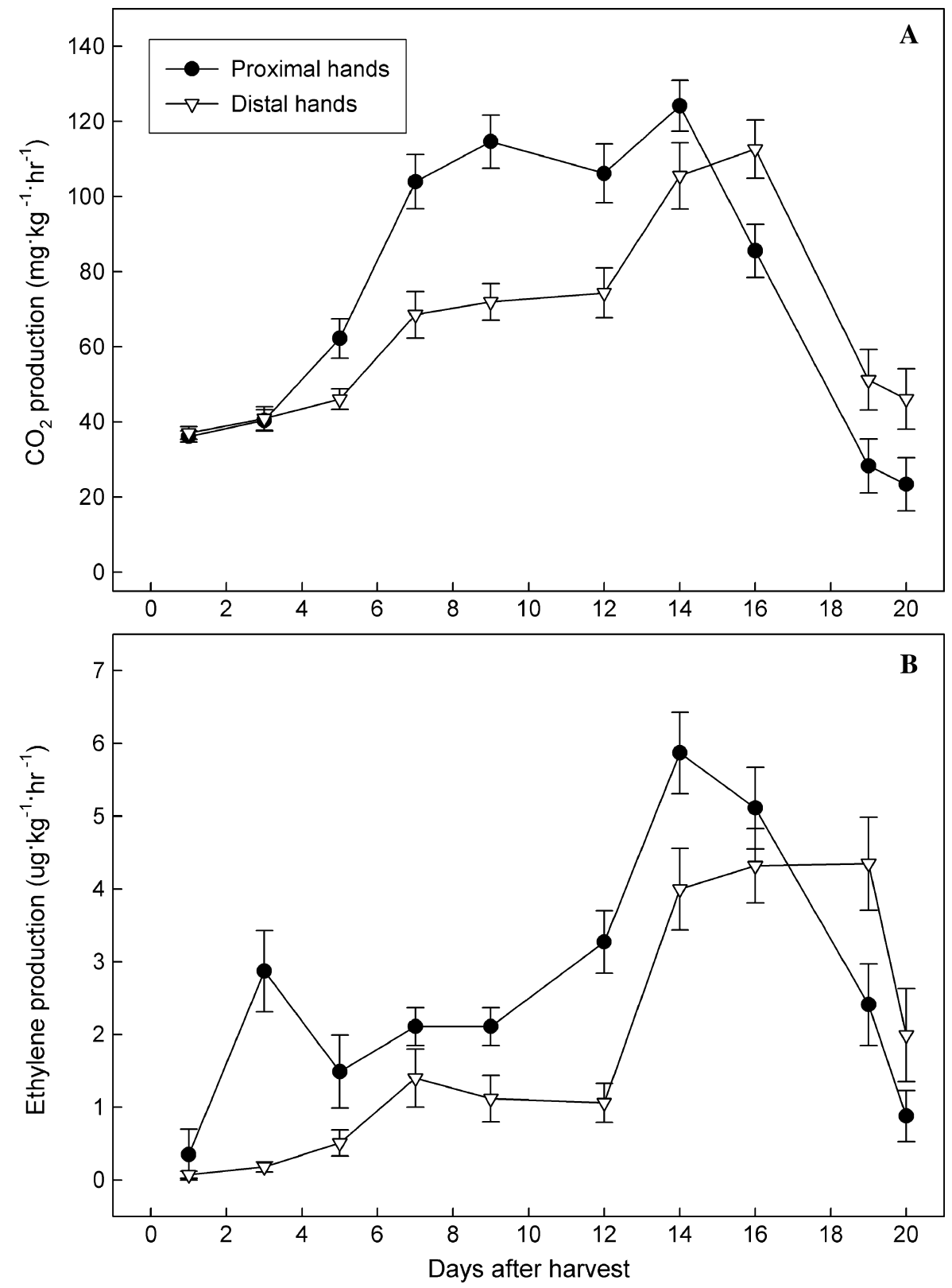

Fig. 1. (A) Carbon dioxide and (B) ethylene production of Dwarf Brazilian bananas harvested from the proximal and distal hands on a bunch. Data were combined over all irradiation treatments for winter and summer experiments.

tion rates in response to treatment (Strydom and Whitehead, 1990). The preclimacteric increase in respiration may reflect an enhanced energy need by cells damaged from free radicals generated during irradiation treatment. Ethylene production rates also increased on day 3 for irradiated bananas with the 800 Gy-treated fruit showing the greatest stress response (Fig. 2B). Ethylene peak production occurred on day 14 for bananas treated with 0 or 800 Gy but was delayed for fruit treated with 400 Gy irradiation.

During normal banana ripening, starch is degraded rapidly to sucrose followed by the accumulation of glucose and fructose (Seymour, 1993). An increase in amylase and phosphorylase activities is strongly cor- related with starch degradation during banana ripening (Hubbard et al., 1990; Nascimento et al., 2006). Sucrose is synthesized through the action of sucrose phosphate synthase (SPS) and hydrolyzed to glucose and fructose by acid invertase (Cordenunsi and Lajolo, 1995; Hubbard et al., 1990).

For irradiated bananas, the conversion of starch to sugars during banana ripening was not impaired by treatment (Table 1), indicating that amylases or phosphorylases were not inhibited, although this was not measured directly. Starch concentrations and total sugar concentrations were similar between control fruit and irradiated fruit at all doses $(P>0.05)$. However, sucrose contents decreased linearly as irradiation dose increased, whereas glucose and fructose concentrations 

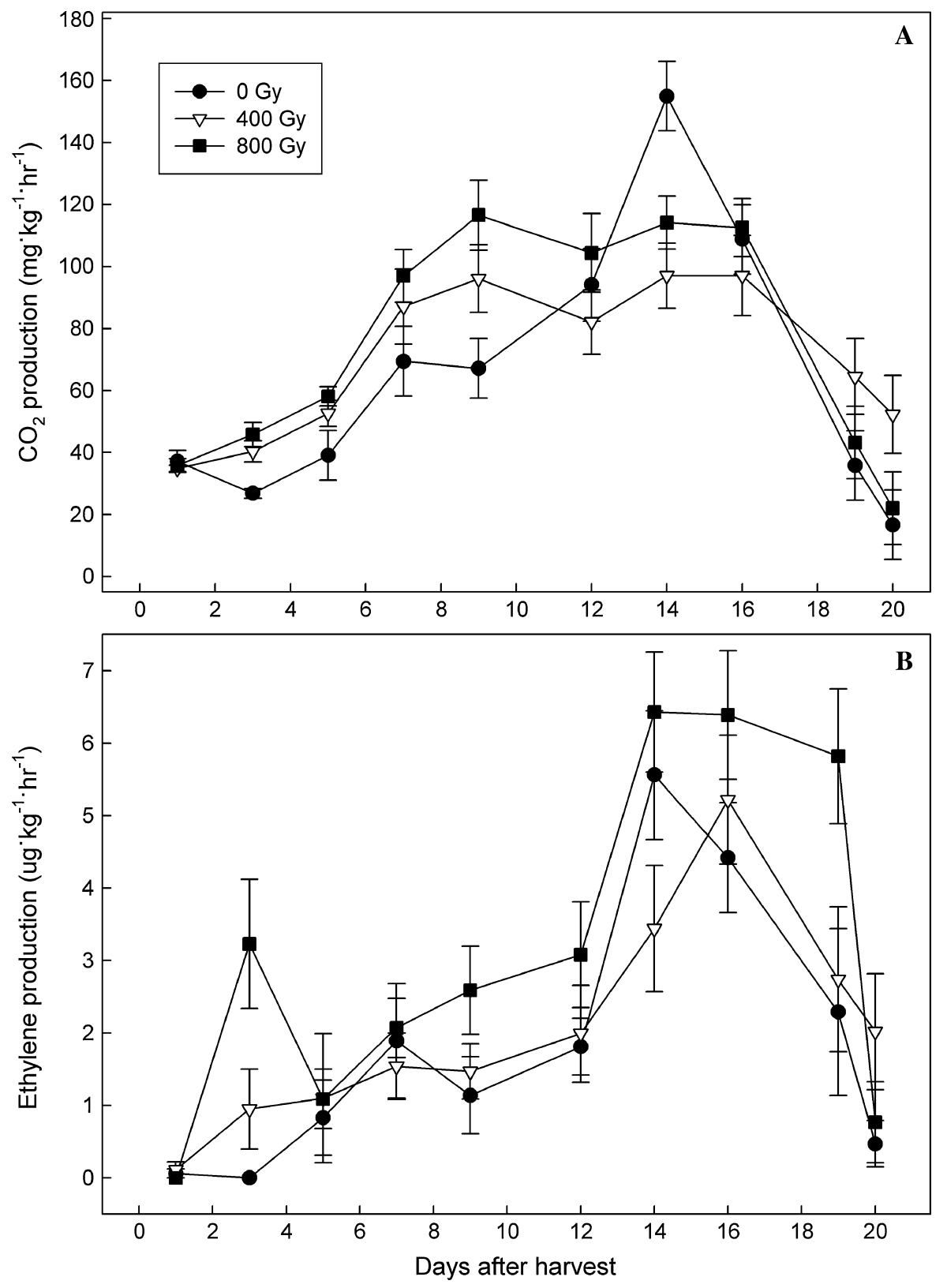

Fig. 2. (A) Carbon dioxide and (B) ethylene production of Dwarf Brazilian bananas after irradiation treatment at 0,400 , or $800 \mathrm{~Gy}$. Rates for bananas treated with 200 and 600 Gy irradiation generally fall between adjacent treatment means. Data were combined for winter and summer experiments and for proximal and distal hands.

increased. Irradiation may stimulate invertase activity, shifting the ratios between sucrose and reducing sugars in ripe bananas. Stone and Cherry (1972) reported increased invertase activity, through enhanced RNA methylation, in irradiated sugar beet roots. In bananas, irradiation may also accelerate the rate of gluconeogenesis (Surendranathan and Nair, 1981) followed by an earlier conversion of sucrose to glucose and fructose when compared with nonirradiated fruit.

Interactions among harvest season, hand position, and irradiation dose impacted fruit firmness, peel color, and injury $(P \leq 0.05)$. For winter-harvested fruit, irradiation affected the firmness of the peel but not the mer months (Tables 2 and 3). Summerharvested fruit also were damaged at the $600-G y$ dose for distal fruit only. Scald ratings were confirmed with colorimeter measurements. As irradiation dose increased, a linear decrease in peel lightness, chroma, and hue angle was observed indicating a darker, duller peel color when scald developed at the highest dose. Peel discoloration has been attributed to induction of polyphenol oxidase (PPO) activity in irradiated bananas (Thomas and Nair, 1971). Differences in fruit maturity (proximal versus distal hands) may impact the ability to repair oxidative damage from irradiation stress. For proximal fruit, respiration and ethylene rates increased during the preclimacteric stage after irradiation treatment (Fig. 1), indicating a metabolic increase in energy demand to repair damaged cells. For less mature distal fruit, the physiological response may not be sufficient to avoid membrane damage after irradiation treatment, resulting in the reaction of phenolic substrates with PPO to produce browning compounds in peel cells.

Bunches were harvested $\approx 19$ and 17 weeks after flower emergence for winter and summer experiments, respectively. Under these conditions, only hands from the proximal half of bunches should be treated at doses $\leq 600$ Gy to ensure visual quality of Dwarf Brazilian bananas. With other banana types, the maximum tolerable dose varied with cultivar, but generally irradiation doses $>500$ Gy caused peel damage (Aina et al., 1999; Thomas et al., 1971). It seems likely that Dwarf Brazilian bananas are more radiotolerant than Cavendish-type cultivars, although the dosimetry used in earlier research often was not described, leading to uncertainty over the actual dose that the fruit received.

Exporters using irradiation for quarantine security can develop markets for Dwarf Brazilian bananas with confidence that quality, composition, and ripening behavior will not be compromised by doses $\leq 600$ Gy for mature, preclimacteric fruit. If fruit are treated with a minimum absorbed dose of 400 Gy, then inspections are required only for banana moth pupae and adults (Federal Register, 2006). However, the current USDA APHIS rule also allows for a minimum dose of 150 Gy with inspection for banana moth and green scale (Federal Register, 2006). New data show that irradiation at $120 \mathrm{~Gy}$ sterilizes banana moth pupae (the most radiotolerant stage), and entomologists are collecting data on the radiotolerance of green scale (R. Hollingsworth and P. Follett, personal communication, 15 Aug. 2006). Eventually, a USDA APHIS rule may be issued that allows movement of Hawaii's bananas after irradiation with 150 Gy to provide security against all fruit flies and surface pests of quarantine importance without the need for inspections. Under this scenario, bananas treated with a minimum dose of $150 \mathrm{~Gy}$ would experience a maximum dose $<300$ Gy, well within the fruit tolerance range for maintaining high quality. 
Table 2. Firmness, peel color, and peel injury of winter-harvested Dwarf Brazilian bananas after irradiation treatments, storage at $14{ }^{\circ} \mathrm{C}$ for $7 \mathrm{~d}$, and ripening at $20^{\circ} \mathrm{C}$.

\begin{tabular}{|c|c|c|c|c|c|c|}
\hline \multirow[b]{2}{*}{ Dose (Gy) } & \multicolumn{2}{|c|}{ Firmness $^{z}$} & \multicolumn{3}{|c|}{ Peel color ${ }^{y}$} & \multirow{2}{*}{$\begin{array}{l}\text { Peel injury } \\
\text { rating }^{\mathrm{x}}\end{array}$} \\
\hline & Peel (N) & Pulp (N) & $\mathrm{L}^{*}$ & $\mathrm{C}$ & Hue $\left(^{\circ}\right)$ & \\
\hline \multicolumn{7}{|l|}{ Proximal $^{\mathrm{w}}$} \\
\hline 0 & 13.2 & 4.8 & 70.7 & 47.8 & 89.3 & 0.0 \\
\hline 200 & 16.2 & 5.5 & 71.1 & 44.1 & 89.8 & 0.0 \\
\hline 400 & 17.0 & 5.5 & 68.9 & 47.0 & 88.1 & 0.1 \\
\hline 600 & 18.5 & 5.1 & 68.4 & 44.0 & 88.3 & 0.1 \\
\hline \multirow[t]{2}{*}{800} & 22.6 & 5.5 & 67.3 & 42.8 & 87.6 & 0.2 \\
\hline & $\mathrm{L}^{* * *}$ & NS & $\mathrm{L}^{* * *}$ & $\mathrm{~L}^{* * *}$ & $\mathrm{~L}^{* * *}$ & $\mathrm{~L}^{*}$ \\
\hline \multicolumn{7}{|l|}{ Distal $^{\mathrm{w}}$} \\
\hline 0 & 17.0 & 5.1 & 72.5 & 47.4 & 90.3 & 0.0 \\
\hline 200 & 20.4 & 5.3 & 70.0 & 46.7 & 88.4 & 0.0 \\
\hline 400 & 22.2 & 5.4 & 67.8 & 44.6 & 87.8 & 0.3 \\
\hline 600 & 25.4 & 5.8 & 66.9 & 44.2 & 87.4 & 0.2 \\
\hline \multirow[t]{2}{*}{800} & 18.7 & 5.1 & 62.5 & 40.9 & 85.1 & 1.4 \\
\hline & $\mathrm{L}^{*}, \mathrm{Q}^{* * *}$ & NS & $\mathrm{L}^{* * *}$ & $L^{* * *}$ & $\mathrm{~L}^{* * *}$ & $\mathrm{~L}^{* * *}$ \\
\hline \multicolumn{7}{|l|}{ Significance } \\
\hline Block (B) & $* * *$ & $* * *$ & $* * *$ & $* * *$ & $* * *$ & $* *$ \\
\hline Dose (D) & $* * *$ & NS & $* * *$ & $* * *$ & $* * *$ & $* * *$ \\
\hline Hand position $(\mathrm{H})$ & $* * *$ & NS & $* *$ & NS & $* *$ & $* *$ \\
\hline $\mathrm{D} * \mathrm{H}$ & $* * *$ & NS & ** & $*$ & ** & $* * *$ \\
\hline
\end{tabular}

${ }^{\mathrm{z}}$ Firmness values are means of 12 observations.

${ }^{y}$ Lightness $\left(\mathrm{L}^{*}\right)$ is on a scale of 0 to 100 . Chroma (C) is on a scale of 0 to 60 , with full saturation at 60 . A hue angle of $90^{\circ}=$ yellow. Values are means of 16 observations.

${ }^{x}$ Peel injury (scald) was assessed visually and rated as the percentage of the surface area showing grayish discoloration, in which $0=0 \%, 1=20 \%, 2=21 \%$ to $40 \%, 3=41 \%$ to $60 \%, 4=61 \%$ to $80 \%$, and $5=81 \%$ to $100 \%$.Values are means of 16 observations.

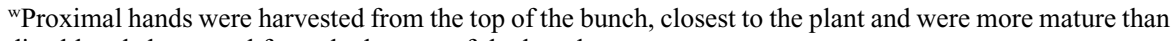
distal hands harvested from the bottom of the bunch.

NS, ****,*** Nonsignificant or significant at $P \leq 0.05,0.01$, or 0.001 , respectively. Significant dose-response trends were linear $(\mathrm{L})$ or quadratic $(\mathrm{Q})$.

Table 3. Firmness, peel color, and peel injury of summer-harvested Dwarf Brazilian bananas after irradiation treatments, storage at $14^{\circ} \mathrm{C}$ for $7 \mathrm{~d}$, and ripening at $20^{\circ} \mathrm{C}$.

\begin{tabular}{|c|c|c|c|c|c|c|}
\hline \multirow[b]{2}{*}{ Dose (Gy) } & \multicolumn{2}{|c|}{ Firmness $^{\mathrm{z}}$} & \multicolumn{3}{|c|}{ Peel color ${ }^{\mathrm{y}}$} & \multirow[b]{2}{*}{ Peel injury rating ${ }^{x}$} \\
\hline & Peel $(\mathrm{N})$ & Pulp (N) & $\mathrm{L}^{*}$ & $\mathrm{C}$ & Hue $\left({ }^{\circ}\right)$ & \\
\hline \multicolumn{7}{|l|}{ Proximal $^{w}$} \\
\hline 0 & 16.6 & 4.9 & 71.8 & 48.2 & 90.9 & 0.0 \\
\hline 200 & 14.6 & 4.8 & 71.0 & 48.6 & 89.9 & 0.0 \\
\hline 400 & 16.2 & 5.6 & 71.3 & 47.3 & 90.5 & 0.0 \\
\hline 600 & 17.4 & 5.5 & 70.2 & 47.5 & 89.5 & 0.0 \\
\hline \multirow[t]{2}{*}{800} & 18.9 & 5.1 & 70.1 & 46.8 & 89.6 & 0.2 \\
\hline & $\mathrm{L}^{*}$ & $\mathrm{~L}^{*}$ & $\mathrm{~L}^{* * *}$ & NS & $\mathrm{L}^{* * *}$ & $\mathrm{~L}^{*}$ \\
\hline \multicolumn{7}{|l|}{ Distal $^{\mathrm{w}}$} \\
\hline 0 & 17.0 & 5.2 & 71.7 & 52.1 & 90.4 & 0.0 \\
\hline 200 & 18.6 & 5.5 & 71.3 & 50.3 & 89.9 & 0.0 \\
\hline 400 & 18.3 & 4.7 & 69.3 & 48.3 & 88.7 & 0.0 \\
\hline 600 & 19.4 & 5.4 & 68.1 & 46.4 & 88.8 & 1.3 \\
\hline \multirow[t]{2}{*}{800} & 18.5 & 5.1 & 60.9 & 40.7 & 85.1 & 2.4 \\
\hline & NS & NS & $\mathrm{L}^{* * *}$ & $\mathrm{~L}^{* * *}$ & $\mathrm{~L}^{* * *}$ & $\mathrm{~L}^{* * *}$ \\
\hline \multicolumn{7}{|l|}{ Significance } \\
\hline Block (B) & NS & $* * *$ & $* * *$ & $*$ & $* * *$ & $*$ \\
\hline Dose (D) & NS & NS & $* * *$ & $* * *$ & $* * *$ & $* * *$ \\
\hline Hand position $(\mathrm{H})$ & $*$ & NS & $* * *$ & NS & $* * *$ & $* * *$ \\
\hline $\mathrm{D} * \mathrm{H}$ & NS & ** & $* * *$ & $* * *$ & $* * *$ & $* * *$ \\
\hline
\end{tabular}

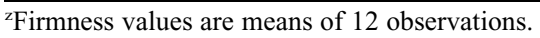

y Lightness ( $\left.\mathrm{L}^{*}\right)$ is on a scale of 0 to 100 . Chroma $(\mathrm{C})$ is on a scale of 0 to 60 , with full saturation at 60 . A hue angle of $90^{\circ}=$ yellow. Values are means of 16 observations.

${ }^{x}$ Peel injury (scald) was assessed visually and rated as the percentage of the surface area showing grayish discoloration, in which $0=0 \%, 1=20 \%, 2=21 \%$ to $40 \%, 3=41 \%$ to $60 \%, 4=61 \%$ to $80 \%$, and $5=81 \%$ to $100 \%$. Values are means of 16 observations.

wroximal hands were harvested from the top of the bunch, closest to the plant and were more mature than distal hands harvested from the bottom of the bunch.

Ns, $, * * *, * * *$ Nonsignificant or significant at $P \leq 0.05,0.01$, or 0.001 , respectively. Significant dose-response trends were linear $(\mathrm{L})$.

\section{Literature Cited}

Aina, J.O., O.F. Adesiji, and S. Ferris. 1999. Effect of gamma irradiation on post-harvest ripening of plantain fruit (Musa paradisiaca) cultivars. J. Sci. Food Agr. 79:653-656. nean and oriental fruit flies (Diptera: Tephritidae) in Hawaii. J. Econ. Entomol. 94:302-314.

Blakeney, A.B. and L.L. Mutton. 1980. Simple colorimetric method for the determination of sugars in fruit and vegetables. J. Sci. Food Agr. 31:889-897.

Cordenunsi, B.R. and F.M. Lajolo. 1995. Starch breakdown during banana ripening: Sucrose synthase and sucrose phosphate synthase. J. Agr. Food Chem. 43:347-351.

Del Monte Fresh Produce. 1992. The banana ripening manual. Del Monte Fresh Produce Co., Coral Gables, Fla.

Eric, B., J. Le Compte, S. Klein, and W. Kricker. 1970. Study of disinfestation of bananas by gamma irradiation. Food Tech. Australia 22:664-667.

Federal Register. 2006. Treatment for fruits and vegetables. Rules and Regulations 71:44514464. 27 Jan. 2006.

Ferguson, W.E., A.R. Yates, K.F. MacQueen, and J.A. Robb. 1966. The effects of gamma radiation on bananas. Food Technol. 20:203-205.

Follett, P.A. 2006. Irradiation as a phytosanitary treatment for Aspidiotus destructor (Homoptera: Diaspididae). J. Econ. Entmol. 99:1138-1142.

Hagenimana, V., R.E. Simard, and L. Vezina. 1994. Amylolytic activity in germinating sweetpotato (Ipomoea batatas L.) roots. J. Amer. Soc. Hort. Sci. 119:313-320.

Hubbard, N.L., D.M. Pharr, and S.C. Huber. 1990. Role of sucrose phosphate synthase in sucrose biosynthesis in ripening bananas and its relationship to the respiratory climacteric. Plant Physiol. 94:201-208.

Maxie, E.C., R. Amezquita, B.M. Hassan, and C.F. Johnson. 1968. Effect of gamma irradiation on the ripening of banana fruits. Proc. Amer. Soc. Hort. Sci. 92:235-254.

Nascimento, J.R.O., A.V. Junior, P.Z. Bassinello, B.R. Cordenunsi, J.A. Mainardi, E. Purgatto, and F.M. Lajolo. 2006. Beta-amylase expression and starch degradation during banana ripening. Postharvest Biol. Technol. 40:41-47.

SAS Institute. 1999. SAS system for Windows, version 8. Cary, N.C.

Seymour, G.B. 1993. Banana. pp. 83-106. In: G. Seymour, J. Taylor, and G. Tucker (eds.), Biochemistry of fruit ripening. Chapman and Hall, London.

Simmonds, N.W. 1954. Notes on banana varieties in Hawaii. Pacific Science. 8:226-229.

Stone, B.P. and J.H. Cherry. 1972. Induced production of invertase in sugar-beet root by $\gamma$ irradiation: Role of RNA. Planta 102:179-189.

Strydom, G.J. and C.S. Whitehead. 1990. The effect of ionizing radiation on ethylene sensitivity and postharvest ripening of banana fruit. Scientia Hort. 41:293-304.

Surendranathan, K.K. and P.M. Nair. 1981. Gluconeogenesis in $\gamma$-irradiated preclimacteric Cavendish banana and its significance in delay of ripening. Indian J. Biochem. Biophys. 18:281-285.

Thomas, P., S.D. Dharkar, and A. Sreenivasan. 1971. Effect of gamma irradiation on the postharvest physiology of five banana varieties grown in India. J. Food Sci. 36:243-247.

Thomas, P. and P.M. Nair. 1971. Effect of gamma irradiation on polyphenol oxidase activity and its relation to skin browning in bananas. Phytochem. 10:771-777.

Wall, M.M. 2004. Ripening behavior and quality of Brazilian bananas (Musa sp.) following hot water immersion to disinfest surface insects. HortScience. 39:1349-1353.

Wall, M.M. 2006. Ascorbic acid, vitamin A and mineral composition of banana (Musa sp.) and papaya (Carica papaya) cultivars grown in Hawaii. J. Food Comp. Anal. 19:434-445. 